\title{
Mean Rate of Gully Head Advancement in Edo State, Nigeria
}

\author{
Augustine Osayande* and Ishaku Ibrahim Yari Mallo
}

Department of Geography and Environmental Management, University of Abuja, Nigeria

\begin{abstract}
The issue of gully erosion is of major concern in Nigeria. The study was carried out in Edo state, Southern Nigeria. Edo State was chosen as the study area due to the fact that the magnitude of gully erosion has resulted in the loss of lives and properties, destruction of arable lands and wastage of large areas of usable land. In this study, an effort was made to identify the major gully sites in the area and determined the mean rate of gully head advancement. The result revealed that gullies in Edo North had mean rate of head advancement of 80.30 meters per a year, Edo South 52.03 meters per a year and Edo Central is 17.80 meters per year.
\end{abstract}

Keywords: gully, erosion, head, advancement, rate, meters.

\section{Introduction}

Gully erosion is the removal of soil and soft rock because of concentrated runoff that forms a deep channel. Poesen $e t$ al. [1] defined gully erosion as the erosion process whereby runoff water accumulates and often recurs in narrow channels and, over short periods, removes the soil from this narrow area to considerable depths. According to Amangabara et al [2], gully erosion is the terminal phase of a four-stage erosion process involving splash, sheet, rill, and gully. The process begins by water falling as raindrops and flowing on the soil surface.

Splash erosion results when the force of raindrops falling on bare or sparsely vegetated soil detaches soil particles. Radoane et al. [3] observed that gullies are important part of soil erosion process and their occurrence and development may cause serious problems to a region's economy. Gully is normally formed on very steep land, where water running downhill cuts a channel deep into the soil. Gobena [4]

* Corresponding author email: austinelande@yahoo.com DOI : https://doi.org/10.21467/ias.3.1.13-18 defined gullies as steep-sided eroding watercourses that are subject to ephemeral flash flood during rainstorms. It also occurred where there is a sudden fall. According to Eseigbe et al. [5], gully erosion is a serious form of soil degradation often involving an initial incision in to the subsurface, by concentrated runoff along lines or zones of weakness such as tension and desiccation fractures. These narrow incisions are subsequently widened and elongated by sidewall processes and headward erosion. Aderemi et al. [6] observed that gullies may also be initiated at the local base level streams and rivers by the combined effects of seepage forces, subterranean erosion and liquefaction. Gullies of this type develop into gigantic negative relief features by progressive liquefaction, flowage, progressive tension fracturing, slumping and landslides. Gully erosion is essentially a slope failure phenomenon operating under the influence of hydrodynamic, gravitational and body forces. Slope failure can also proceed through flowage, sliding and slumping, and toppling. Ekpenyong [7], observed that the rates of these failures which culminate to 
gully advance and lateral expansion are more during periods of heavy precipitation.

The control of gully erosion has not been given adequate attention because gully processes are difficult to study and in some cases, the right control measures are not applied. Poesen et al [1] observed that no systematic compilation of length, width, depth of the different types of gullies and their controlling factors in a wide range of environments has been made. Such quantitative data is needed for application of effective. Izinyon et al. [8], argue that gully can be controlled and managed through a combination of structural and non-structural methods consisting of drop structures at the gully head.

\section{Study Area Description}

Edo State is located in the South-South Zone of Nigeria. Its capital town is Benin-city. The State was created in 1991 out of the old Bendel state and its geographical coordinates are Latitudes $05^{\circ}$ $44^{\prime}$ to $07^{\circ} 34^{\prime} \mathrm{N}$ and longitude $05^{\circ} 04^{\prime}$ and $06^{\circ} 45^{\prime}$ E. It has a land mass of $19,794 \mathrm{~km}$ square and it is bordered by Kogi State to the north, Delta State to the East and South and Ondo State to the West. The geology of the study area reveals that the entire area is underlain by sedimentary rocks. It consists of the crystalline basement rocks in the hilly and dissected zone in the north followed southwards by residual lateritic soils of the well drained dry lands at Auchi, Agbede and Afuze.

Aderemi et al [6] observed the area is underlain by sedentary rock of the Pleistocene age often referred to as the Benin formations. The sedimentary rock contains about 90 percent of sandstone and shale intercalation. It consists of over $90 \%$ sandstone, clay, shale and lignite coarse fine grained in some areas. The nature of the underlying geology contributes significantly to the origin and spread of gullies Afegbua et al [9]. The relief of the area is mainly characterized by swamping creeks and dissected plateau such as the Esan Plateau, Orle valley and the dissected uplands of Akoko-Edo Local Government Area. According to Aderemi et al [6], there are six types of physical features which constitute the landscape of the area. Sandy coastal plain and alluvium clay are found in the Benin lowlands area with some hills in the east. Slopes are tilled in the southwest direction. River Osse, River Orihionmwon and lkpoba are the major drain in the area. Except for River Osse that has a wide flood plain, Eseigbe et al [5], observed that other rivers in the area are characterised by steeply incised valleys in their upper courses and they become broad as they enter River Ethiope in Delta State. According to Eseigbe et al [5], the state has land mass that is relatively flat terrain in the southern part with an average height above the sea level of about 500 metres except towards the northern axis where the Northern and Esan plateaus range from 183 metres at the Kukuruku Hills and 672 metres at the Somorika Hills. The climate of the study area is humid sub-tropical indicating that it is basically within the tropical rain forest zone dominated by broadleaved trees that form dense layered stands which usually are above $50 \mathrm{~m}(165 \mathrm{ft})$ in height. It is typically tropical with two major seasons- the wet and the dry seasons. Ikhile [10] highlight that the seasons correspond to the periods of dominance of the wet tropical continental air masses and the seasonal distribution of rainfall follows the direction of the Inter-Tropical Divergence (ITD) which varies almost proportionally with distance from the coast.

The temperatures across the state is relatively high with a very narrow varies in seasonal and diurnal ranges 22-36 range with an average annual rainfall of about between $2000 \mathrm{~mm}-2500 \mathrm{~mm}$. The wet season comes between April and November and the dry season between December and March. According to Onakerhoraye [11], there is a marked dry season, with duration of increases from three months in south, northwards, while the rainy period decreases inland from nine months in the south to five months in the northeast. The vegetation zones of Edo State coincide with the political zones in the state. Edo South is in the moist rainforest, Edo Central in the dry rainforest and derived savanna and Edo North is characterized with derived savanna and southern guinea savanna. The area is also characterized by few scattered rainforests, wooded shrub lands and farmlands. Adekunle $e t$ al [12], observe that the trees could be seen to be green throughout the year because they retain their leaves all through the year. This is because 
the temperature and precipitation are sufficiently high for continuous growth. The state is blessed with abundant natural resources. Virtually all species of hardwood can be found high quality timber is produced from most local government areas of the State.

The state consists of eighteen Local Government Areas (Figure 1) which include Akoko-Edo, Egor, Esan Central, Esan North-East, Esan South-East, Esan West, Etsako Central, Etsako East, Etsako West, Igueben, Ikpoba-Okha, Oredo, Orhionmwon, Ovia North-West, Ovia South-West, Owan East, Owan West and Uhunmwonde.

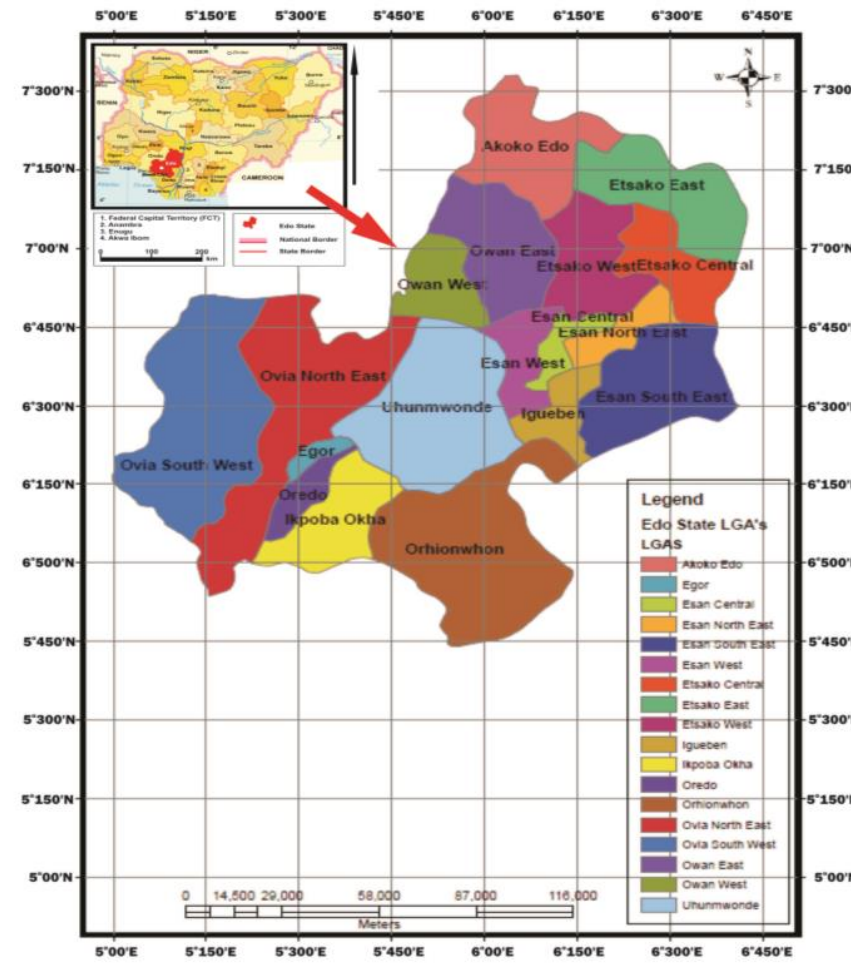

Figure 1: Local Government Areas in Edo State Source: Edo State Ministry of Lands and Surveys

Major towns in the State include Benin City (the State Capital), Abudu, Ekpoma, Uromi, Auchi, and Sabongida-Ora. Generally, Edo State is traditionally known for agriculture, trade and deep historical virtues. The residents are traders and farmers whose activities are closely tied to the land. A lot of residential structures are within the gully strip, Edo State Strategic Health Development Plan (2010-2015) [13]. Due to their proximity to the gully, some of these structures have been marked as danger zones by the Edo State Ministry of Land, Housing and Survey.
According to the State Strategic Health Development Plan [13] 70\% of the landmass is cultivated for agricultural production as a means of livelihood with an average of about 2.345 million persons in the State directly or indirectly engage in agricultural activities. Major ethnic groups in the state are the Binis, the Esan, Ora, Etsakos, Owans, Akoko, Igarra and Afemai. The Binis occupy the southern part of the state, Esan and Ora occupy the central part and Afemai, Igarra and Akoko in the northern area. According to National Population Commission (2006) [14] Edo State has a total population of 3,233,366. The demographic features of the area are typical of states in Southern part of Nigeria, growing rapidly with the population overstretching the weak social services. With the figure of 2006 Population and Housing Census [14], the state has population of 3,233,366 and an average population density for the state is about 109 persons per sq. $\mathrm{km}$, which is above the national average of about 96 persons per sq. $\mathrm{km}$. According to the State Strategic Health Development Plan (2010-2015) [13], the total population figures have been projected to over 3.4 million people. Most people in the area engaged in food crops cultivation. The main food crops cultivated include yam, cassava, maize and rice in the Benin lowlands and on the Esan plateau. There is also rice cultivation in the flood plains of the River Niger at Agenebode and Illushi. Tree crops such as rubber and oil palm are also cultivated in the Benin lowlands and Esan Plateau and cocoa in Owan, Etsako and Akoko Edo. The major environmental and ecological problems associated with Edo State are waste management, pollution and sanitation, forest depletion, flooding and erosion of the surface of the soil. Land degradation due to flooding and erosion ranked first and second in the objective ranking of environmental problems in the state [13].

The magnitude of devastation as a result of flooding and erosion has resulted in loss of lives and properties, destruction of arable lands and wastage of large areas of usable lands. The State Strategic Health Development Plan also suggested need for re-afforestation, regulated construction and provision of drainage facilities 
Mean Rate of Gully Head Advancement in Edo State, Nigeria

in urban areas as well as attitudinal change on the part of the people.

\section{Methodology}

Direct field observation and measurement of gully length and depth was done with the help of research assistants using simple survey equipments (measuring tape, Camera and 3percent accuracy Global Positioning System (GPS). The age of the gully was determined from the record made available by the victims and was supported with historical trace of the major cause of the problem.

The numbers of gullies chosen for the study were determined using the Taro Yamane formula.

$$
n=\frac{N}{1+N(e)^{2}}
$$

Where

$\mathrm{n}=$ sample size

$\mathrm{N}=$ total number of gullies in the state

$\mathrm{e}=$ is the margin of error assumed (0.05)

$1=$ is the theoretical constant

The formula was chosen because it has $95 \%$ confidence level and the total number of gullies in the study area is within ranges of hundred which fit into the basic assumption of the formula.

$$
\begin{aligned}
n=\frac{110}{1+110(0.05)} 2 \\
=\frac{110}{111(2.5)}=0.396
\end{aligned}
$$

\subsection{Basic Assumption}

If the population is a few hundreds, a $40 \%$ sample will do, if many hundreds, a $20 \%$ sample will do. If a few thousands, a 10\% sample and if several thousands, a $5 \%$ or fewer sample will do [15]-

$$
\mathrm{n}=0.396 \times 40 \quad=16
$$

Google Earth Map of Major Gullies Sites in Edo State has been shown in Figure 2. The random sampling technique was used in selecting the 16 gullies sites across the study area. The mean rate of gully head advancement was determined after Mallo [16] using the formula:

$$
R G A=\frac{L G}{A G} \mathrm{~m} / \mathrm{year}
$$

Where:

RGA $=$ Rate of gully head advancement

$\mathrm{LG}=$ Length of gully

AG $=$ Age of gully

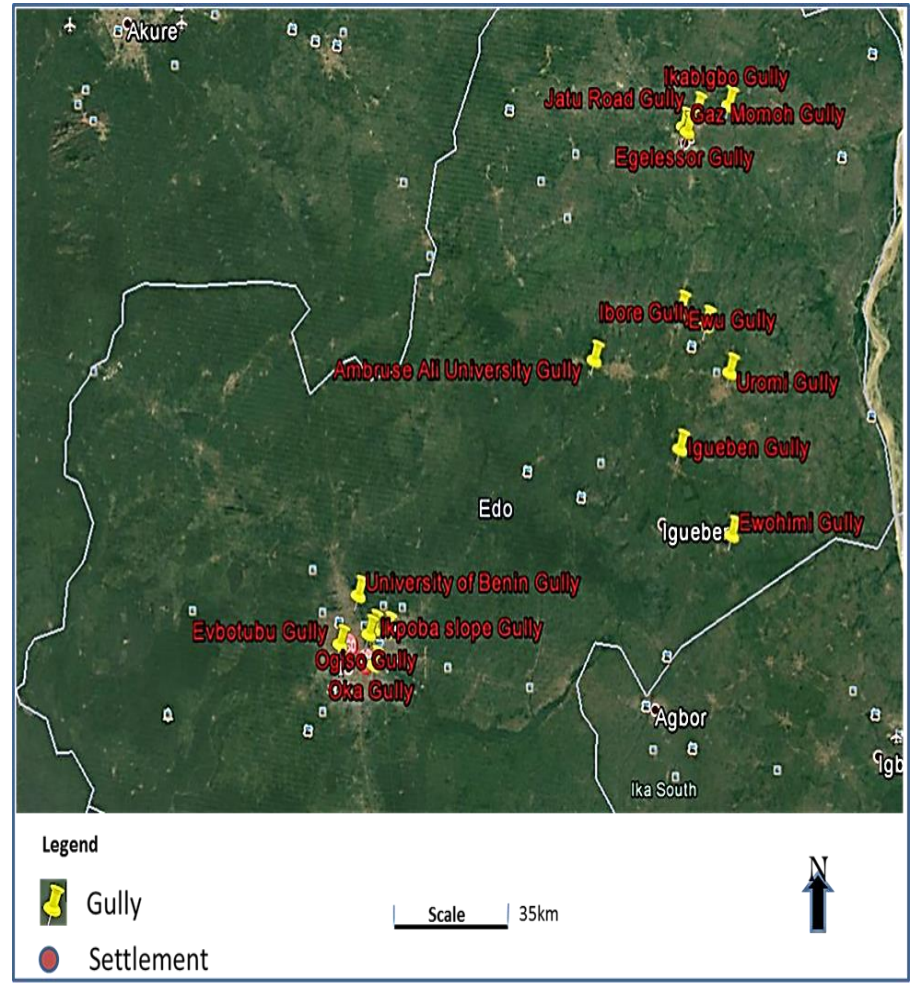

Figure 2: Google Earth Map of Major Gullies Sites in Edo State

\section{Results and Discussion}

The Mean Rate Gully Head Advancement in Edo North is 80.30 meters per a year (Table 1), Edo South is 52.03 meters per a year (Table 2) and Edo Central is 17.80 meters per a year (Table 3). The explanation is that Gullies in Edo North develop faster, followed by Gullies in Edo South and then those in Edo Central. The mean rate of gully head advancement of all gullies sampled is $46.26 \mathrm{~m}$ and the standard deviation of all rate of gully head advancement is 49.59 .

Table 1: Mean Rate of Gully Head Advancement in Edo North

\begin{tabular}{|l|l|l|l|}
\hline \multicolumn{1}{|c|}{ Sites } & $\begin{array}{c}\text { Age } \\
\text { (Years) }\end{array}$ & \multicolumn{1}{c|}{$\begin{array}{c}\text { Length } \\
(\mathbf{m})\end{array}$} & $\begin{array}{c}\text { RGA in } \\
(\mathbf{m} / \mathbf{y e a r})\end{array}$ \\
\hline Ikabigbo Gully & 12 & 202.2 & 16.85 \\
\hline Jatu Road Gully & 6 & 1165 & 194.17 \\
\hline Egelessor Gully & 12 & 423 & 35.25 \\
\hline $\begin{array}{l}\text { Gaz Momoh } \\
\text { Gully }\end{array}$ & 30 & 2248 & 74.93 \\
\hline Total RGA & & & 321.2 \\
\hline Mean RGA & & & $\mathbf{8 0 . 3 0}$ \\
\hline
\end{tabular}


Table 2: Mean Rate of Gully Head Advancement in Edo South

\begin{tabular}{|l|l|l|l|}
\hline \multicolumn{1}{|c|}{ Sites } & \multicolumn{1}{|c|}{$\begin{array}{c}\text { Age } \\
\text { (Years) }\end{array}$} & $\begin{array}{c}\text { Length } \\
(\mathbf{m})\end{array}$ & \multicolumn{1}{c|}{$\begin{array}{c}\text { RGA in } \\
(\mathbf{m} / \text { year })\end{array}$} \\
\hline Oka Gully & 15 & 291.2 & 19.41 \\
\hline Ikpoba Slope Gully & 7 & 837.3 & 119.61 \\
\hline Queen Eden Gully & 37 & 1308 & 35.35 \\
\hline Ogiso Gully & 10 & 357.4 & 35.74 \\
\hline Evbotubu Gully & 15 & 389.8 & 25.99 \\
\hline $\begin{array}{l}\text { University of Benin } \\
\text { Gully }\end{array}$ & 13 & 989.1 & 76.09 \\
\hline Total RGA & & & 312.19 \\
\hline Mean RGA & & & $\mathbf{5 2 . 0 3}$ \\
\hline
\end{tabular}

Table 3: Mean Rate of Gully Head Advancement in

\begin{tabular}{|l|l|l|l|}
\multicolumn{1}{|c|}{ Edo Central } \\
\hline $\begin{array}{l}\text { Ambrose Ali } \\
\text { University Gully } \\
\text { (Ekpoma) }\end{array}$ & $\begin{array}{c}\text { Age } \\
\text { (Years) }\end{array}$ & $\begin{array}{c}\text { Length } \\
(\mathbf{m})\end{array}$ & \multicolumn{1}{c|}{$\begin{array}{c}\text { RGA in } \\
\text { (m/year) }\end{array}$} \\
\hline Igueben Gully & 20 & $149 \mathrm{~m}$ & $16.56 \mathrm{~m}$ \\
\hline Ewohimi Gully & 30 & 312 & 10.40 \\
\hline Uromi Gully & 35 & 316 & 9.03 \\
\hline Ewu Gully & 30 & 213.3 & 7.11 \\
\hline Ibore Gully & 30 & 1125 & 37.50 \\
\hline Total RGA & & & 106.77 \\
\hline Mean RGA & & & $\mathbf{1 7 . 8 0}$ \\
\hline
\end{tabular}

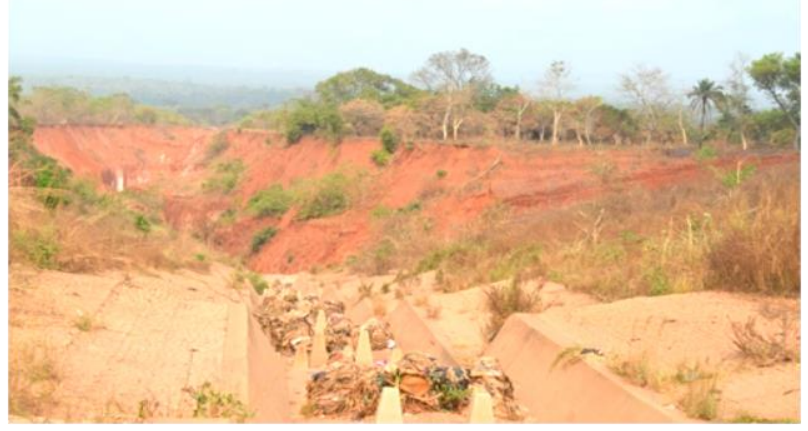

Figure 3: Photo of Jatu Road Gully Site in Edo North

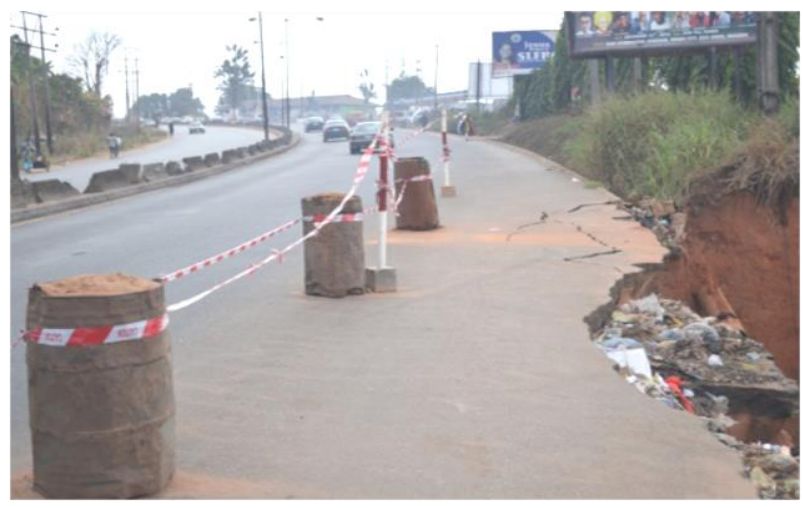

Figure 4: Photo of Ikpoba Slope Gully in Edo South Threatening the Highway

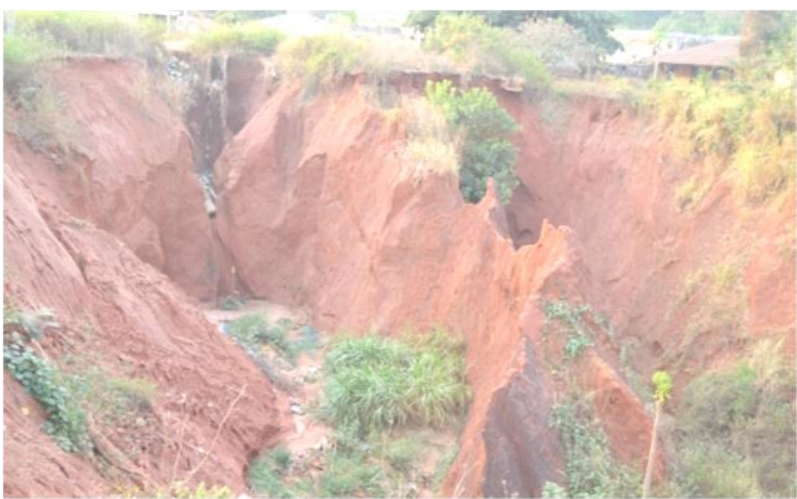

Figure 5: Photo of Ewu Gully Erosion Site Edo Central

Photograph taken at gullies sites are shown in Figure 3 (Edo North), Figure 4 (Edo South) and Figure 5 (Edo Central). The results show that the Mean Rate of Gully Head Advancement in the study area ranges from 80.30 metres per year in Edo North, 52.03 metres in Edo South and 17.80 metres in Edo central but Mallo [16] observed that Rate of Gully Head Advancement at Narayi and Banawa in Kaduna are 5.42 metres and 5.25 metres per year. Also, Mallam et al. [17] observed that gully heads retreated at different rates ranging from $13 \mathrm{~cm}$ to $121 \mathrm{~cm}$ in Kano metropolis. The different causes of gully, soil type and climate are believed to be responsible for the differences observed in the Rate of Gully Head Advancement in the study area and the areas mention.

\section{Conclusion}

Based on the findings of this study, major gullies in the study area continue to expand at an alarming rate and this has increased the vulnerability of the entire area to intensified gully erosion. Although there are some control measures currently in place such as the Nigeria Erosion and Watershed Management Project of 2012 which only covered three sites and some local effort in other sites, but they are not effective to address the extent of gully erosion menace in the area. The menace of gully erosion in areas susceptible like Edo State has called for urgent remedies in order to arrest further loss of land, buildings and other properties. There is need for comprehensive control measures, as the absence or ineffectiveness of the existing measures called for proper land management. 


\section{How to Cite this Article:}

A. Osayande and I. I. Yari Mallo, "Mean Rate of Gully Head Advancement in Edo State, Nigeria" International Annals of Science, vol. 3, no. 1, pp. 13-18, Nov 2017.

doi: https://doi.org/10.21467/ias.3.1.13-18

\section{References}

[1] J. Poesen, J. Nachtergaele, G. Verstraeten, and C. Valentin C, Gully erosion and environmental change: importance and research needs. Laboratory for Experimental Geomorphology, K.U. Leuven, Belgium, Catena 50 91- 133, 2003.

[2] G. T. Amangabara, G. T, Analysis of Selected Failed Gully Erosion Control Works in Imo State. Special Publication of the Nigerian Association of Hydrological Sciences Nigeria (2012) Pages 279-286.

[3] M. Radoane, I. Ionita, and N. Radoane, Gully distribution and development in Moldavia, Romania. Stejarul Research Station, Piatra Neamt, Romania Catena 24, pp 127-146, 1995.

[4] Y.J.Gobena Y.J. (2003), Soil Erosion Assessment Using Remotely Sensed Data and Ancillary Data in the Desert of Tabernas Southeast Spain. International Institute for Geo Information Science and Earth Observation Enschede, Netherlands (2003)

[5] J.O.Eseigbe, and M.O. Ojeifo, Aspects of Gully Erosion in Benin City Edo State, Nigeria. Research on Humanities and Social Sciences, 2(7) 2012.

[6] A. Aderemi, and F. Iyamu, Risk Assessment Analysis of Accelerated Gully Erosion in Ikpoba Okha Local Government Area of Edo State. Nigeria Environment and Natural Resources Research, Canadian Center of Science and Education; (2013) 3(1) Pg 68-76.

[7] R. E. Ekpenyong, An Assessment of Land Cover Change and Erosion risk in Akwa Ibom State of Nigeria using the Coordination of information on the Environment (CORINE) methodology. Greener Journal of Physical Sciences $\backslash$ (2013) 3(3), pages 076-089.

[8] O.C.Izinyon, J.O.Ehiorobo and A.C.Adedeji, Appraisal of Structural and non-Structural Approaches to Gully Erosion Control. A Case Study of Queen Ede Gully Site in Benin City, Department of Civil Engineering, University of Benin. (2012)

[9] U.K.Afegbua, J. Uwazuruonye, and B. Jafaru, Investigating the Causes and Impacts of Gully Erosion in Auchi, Nigeria. Journal of Geography, Environment and Earth Science International SCIENCEDOMAIN international 4(4): 1-13, 2016.

[10] C.I Ikhile, Climate change and erosion activities in Benin-Owena River Basin, South West Nigeria. Journal of Geography and Regional Planning (2015) 99-110.

[11] A. G. Onokerhoraye, Urbanization and Environment in Nigeria: Implications for Sustainable Development. The Benin Social Science Series for Africa. Benin City: University of Benin 1995.

[12] V. A. J. Adekunle, A.O.Olagoke and L.F.Ogundare, Logging Impacts in Tropical Lowland Humid Forest on Tree Species Diversity and Environmental Conservation. Applied Ecology and Environmental Research (2013) 11(3): 491-511.

[13] Edo State Government, Strategic Health Development Plan (2010-2015). Edo State Ministry of Health (2010)
[14] National Population Commission, Nigeria, 2006. http://population.gov.ng/coreactivities/surveys/dataset/2006-phc-priority-tables/

[15] Ezeigwe, Patrick C., "Evaluation of the Socio-Economic Impacts of Gully Erosion in Nkpor and Obosi", Civil and Environmental Research, vol 7, no 7, pp 34-48, 2015.

[16] Mallo I.I.Y, Hydrological Response to Scarification in Kaduna Urban Environment, Northern Nigeria. Z.Geomorp N.F. Suppl. Bd 103, Berlin-Stuttgart, Germany. (1996) Pp 123-134

[17] I. Mallam, E.O.Iguisi and Y.R.Tasi'u, An Assessment of Gully Erosion in Kano Metropolis, Nigeria. Global Advanced Research Journal of Agricultural Science (2016) Vol. 5(1) pp 014-027.

Publish your research article in AIJR journals-

$\checkmark$ Online Submission and Tracking

$\checkmark$ Peer-Reviewed

$\checkmark$ Rapid decision

$\checkmark$ Immediate Publication after acceptance

$\checkmark \quad$ Articles freely available online

$\checkmark \quad$ Retain full copyright of your article.

Submit your article at journals.aijr.in 